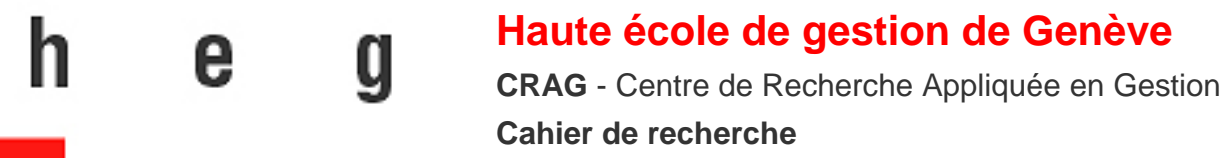

\title{
The End of Compulsory School for Migrants: One More Year for Low- Track Students
}

Joelle Latina and José V. Ramirez

Cahier : No HES-SO/HEG-GE/C--12/2/1--CH

2012 


\title{
The End of Compulsory School for Migrants: One More Year for Low-Track Students
}

\author{
Joelle Latina and José V. Ramirez
}

Working Paper

January 2012

\begin{abstract}
Summary
Integration of migrants into the host country depends on many factors. Using a typology based on different forms of capital (financial and human, social, and political), we focus on migrant integration into the Swiss schooling system, as expressed by their track choice at the upper-secondary level. In particular, we examine whether school transitions of children from certain migrant communities are negatively affected by a lack of social capital. To do so, we estimate a reduced-form multinomial logit, using longitudinal data from the Canton of Geneva (Switzerland), for the period 1990-2007. While differing substantially between high-track and low-track students, results confirm our expectations: first, social capital matters independently of human and financial capital; second, while affecting all students, the impact of a lack of social capital is higher on high-track students. However, the accumulation of social capital, trough experience inside the schooling system, plays generally a greater role for low-track students, but results differ when several profiles of students are considered. In particular, among low-track male students, recent migrants are disadvantaged, compared to natives and first-wave migrants, as they are, ceteris paribus, more often oriented toward non-certifying remedial education. For both types of students, nationality dummies remain significant, suggesting that other factors are at play, such as cultural orientation towards effort or reception of a particular community in the destination country. Finally, structural compositions of middle schools explain almost all the remaining differences between schools (i.e. school effects), once individual and familial characteristics have been considered: while sharing the same school, low-track and high-track students face different socioeconomic and sociodemographic external effects on their transition probabilities.
\end{abstract}

Keywords: education, migrant integration, multinomial logit model, school composition effects, transitions, tracking.

JEL classification: 121, 128, J15. 


\section{Résumé}

Dans la plupart des pays occidentaux, l'augmentation de l'hétérogénéité de la population ne va pas sans poser de problèmes. En particulier, la manière dont les enfants de migrants sont intégrés dans le système scolaire présente un certain nombre de défis pour les pays d'accueil.

Dans cet article, nous examinons l'intégration scolaire des enfants migrants en nous focalisant sur leurs choix d'orientation à la fin de l'école obligatoire (cycle d'orientation). Nous empruntons le cadre théorique de Bourdieux (1986) et Coleman (1988), qui ajoutent aux formes classiques de capital (financier et humain) une troisième dimension : le capital social. Dans le contexte spécifique de la migration, Rumbaut (1998) nous offre une typologie des ressources et vulnérabilités associées à chaque immigrant. Celles-ci s'articulent autour de trois points : les ressources associées à la classe sociale (le capital financier et humain), le statut légal dans le pays d'accueil (le capital politique) et le réseau social, la structure et la cohésion familiale (le capital social). En particulier, le capital social couvre aussi les aspects liés à l'accès à l'information, y compris au fonctionnement du système scolaire, accès qui est reconnu plus difficile pour les familles de migrants (CDIP, 2011). Cette typologie nous guidera dans le choix de nos variables explicatives, afin d'éclairer notre question de recherche : à parité d'autres choses, les enfants de migrants sont-ils défavorisés dans leurs choix d'orientation post-obligatoire?

Notre cas d'étude est le système scolaire genevois sur la période 1990-2006; un système caractérisé par une forte hétérogénéité de la population scolaire et un niveau de dépenses publiques élevé (relativement à la Suisse et à l'OCDE) pour le secondaire I. Grâce à des données administratives (Base de Données Scolaires), nous sommes à même de suivre les enfants durant toute leur scolarité obligatoire et post-obligatoire. Soucieux d'une grande homogénéité de l'échantillon, nous ne basons notre analyse que sur les cycles ayant existé durant toute la période, les élèves n'ayant pas changé de bâtiment durant leurs années de cycle d'orientation et ne considérons que les cycles utilisant le système des sections. En effet, le secondaire I est un système majoritairement hétérogène où les élèves sont répartis entre deux sections à exigences différenciées, avec une section à hautes exigences (section $\mathrm{A}$ ) et l'autre à exigences moindres (section $\mathrm{B}$ ).

Nous analysons la première transition vers le post-obligatoire au moyen d'un modèle économetrique, le logit multinomial. Ce dernier nous permet de prendre en compte un ensemble de variables explicatives et de tenir compte simultanément des multiples possibilités d'orientations au secondaire II. Ces dernières sont regroupées en six catégories, le collège (voie académique), l'école de culture générale, la formation professionnelle à plein temps, la formation professionnelle duale, les passerelles et transitions provisoires et la sortie du système scolaire publique. Nous estimons deux modèles, un pour chaque section du cycle d'orientation ( $A$ et $B$ ). Les variables explicatives sont les mêmes pour chacun des modèles et sont les suivantes: le genre, le fait d'avoir redoublé, l'âge (scolaire) d'arrivée à l'intérieur du système, la catégorie socioprofessionnelle, la structure familiale, la langue parlée à la maison, l'origine et la nationalité. Des effets fixes années et écoles sont également ajoutés, afin de prendre en compte, respectivement, un impact lié à une année affectant tous les enfants et toutes les écoles (e.g. réforme du secondaire II), ainsi qu'un impact propre à chaque établissement affectant tous les élèves d'une même école sur toute la période (e.g. effet lié au management particulier d'une école).

Notre évidence empirique nous amène à répondre positivement à notre question de recherche, les élèves migrants semblent effectivement défavorisés dans leurs choix d'orientation, mais tous les migrants ne sont pas placés à la même enseigne. Bien qu'un déficit de capital social affecte particulièrement les étudiants de section A, l'expérience acquise au sein du système scolaire joue un rôle plus important pour les élèves de section $B$. Cependant les résultats diffèrent lorsque plusieurs 
profils d'élèves sont envisagés. En particulier, parmi les garçons de section $B$, les migrants les plus récents (i.e. appartenant aux vagues migratoires récentes: Balkans et Turques, et migrants noneuropéens) sont désavantagés par rapport aux élèves suisses comparables, parce que les premiers sont plus souvent orientés vers les passerelles et solutions transitoires (environ une fois sur trois, contre une fois sur cinq pour les élèves suisses) et accèdent moins souvent à la formation professionnelle duale (moins d'une fois sur cinq contre un peu plus d'une fois sur trois), à parité d'autres choses. Toujours concernant les élèves de sections $B$, les migrants appartenant aux premières vagues migratoires (bassin Méditerranéen) diffèrent peu dans leurs orientations postobligatoires, en comparaison de leurs pairs suisses, et affichent une probabilité équivalente de transition vers la voie professionnelle duale. Les résultats pour chaque section indiquent que les nationalités jouent un rôle à elles-seules, reflétant l'influence d'autres facteurs propres à une communauté donnée, tels qu'une culture de l'effort ou encore la perception des membres d'une communauté dans le pays d'accueil (e.g. préjugés, stéréotypes). Enfin, la composition des populations scolaires de chaque établissement explique dans une large mesure les effets associés aux écoles, une fois que les caractéristiques individuelles et familiales ont été prises en considération. Ce qui suggère que l'impact du management au niveau de l'établissement est grandement influencé par la composition socioéconomique et sociodémographique de la population d'élèves. La composition ethnique et socioéconomique de la population d'une école influence différemment les élèves de section $A$ et ceux de section $B$ et, à l'intérieur d'une même section, affecte inégalement les probabilités individuelles de transitions vers les divers choix du post-obligatoire. 


\title{
The End of Compulsory School for Migrants: One More Year for Low-Track Students
}

\author{
Joelle Latina and José V. Ramirez* \\ Geneva School of Business Administration and Geneva Leading House in Education Economics
}

\begin{abstract}
Integration of migrants into the host country depends on many factors. Using a typology based on different forms of capital (financial and human, social, and political), we focus on migrant integration into the Swiss schooling system, as expressed by their track choice at the upper-secondary level. In particular, we examine whether school transitions of children from certain migrant communities are negatively affected by a lack of social capital. To do so, we estimate a reduced-form multinomial logit, using longitudinal data from the Canton of Geneva (Switzerland), for the period 1990-2007. While differing substantially between high-track and low-track students, results confirm our expectations: first, social capital matters independently of human and financial capital; second, while affecting all students, the impact of a lack of social capital is higher on high-track students. However, the accumulation of social capital, trough experience inside the schooling system, plays generally a greater role for low-track students, but results differ when several profiles of students are considered. In particular, among low-track male students, recent migrants are disadvantaged, compared to natives and first-wave migrants, as they are, ceteris paribus, more often oriented toward non-certifying remedial education. For both types of students, nationality dummies remain significant, suggesting that other factors are at play, such as cultural orientation towards effort or reception of a particular community in the destination country. Finally, structural compositions of middle schools explain almost all the remaining differences between schools (i.e. school effects), once individual and familial characteristics have been considered: while sharing the same school, low-track and high-track students face different socioeconomic and sociodemographic external effects on their transition probabilities.

Keywords: education; migrant integration; multinomial logit model; school composition effects; transitions; tracking.
\end{abstract}

JEL classification: I21 I28 J15

${ }^{*}$ Geneva School of Business Administration, 7 Route de Drize, 1227 Carouge, Switzerland. Emails: joelle.latina@hesge.ch and jose.ramirez@hesge.ch.

Both authors would like to thank the Canton of Geneva, the Cantonal Department of Public Education (DIP) and the Research Department in Education (SRED). Funding was provided by the Federal Office for Professional Education and Technology. 


\section{Introduction}

In many western countries, increasingly heterogeneous populations are impacting the way migrants and, especially, their children are integrated into the host country. The relevant literature identified several factors influencing the integration process into the schooling system. For instance, cross-country evidence from PISA confirms the idea that early tracking during compulsory school increases inequality between natives and migrants (Hanushek and Woessman, 2006. Schneeweis, 2011). A result that is even more prevalent for children from lower socioeconomic and sociocultural backgrounds (Dustmann, 2004, OECD, Program for International Student Assessment, 2007). In addition, recent empirical researches, benefiting from administrative data, show that, in heterogeneous contexts, teacher-student interactions may distort student evaluation concerning abilities, efforts and attitudes (see, for instance, Dee, 2005). Such evidence suggests that, contrary to what human capital theories put forward, allocation of students to curriculum opportunities can not be considered as the result of an objective assessment of students' relevant abilities and interest, particularly in a highly heterogeneous school. While teachers' perceptions and practices at the establishment level may be consistent with a human capital perspective, students track assignments may be more the result of a "dynamic related to structural, cultural and political factors" (Oakes and Guiton, 1995).

In this paper, we focus on migrant integration in the Swiss schooling system, as expressed by their track choice at the upper-secondary level. Among OECD countries, Switzerland exhibits several peculiarities. First, since each Canton ${ }^{11}$ has enough policy space to shape its schooling system, intensity and age of tracking during compulsory school vary from one canton to another ${ }^{2}$. Second, along Australia, it has more than $30 \%$ of foreign-born population and, ahead of Germany, the highest proportion (more than $50 \%$ ) of young people opting for a dual vocational education and training (VET), implying that apprentices share their weekly time between a professional school and on-the-job training. This historically massive orientation toward VET has often been considered as the main success factor explaining upper-secondary achievements and school-to-work transitions (Fuentes, 2011). However, when controlling for GDP per capital and education attainment in the parent generation, educational outcomes in Switzerland appear less favorable; moreover, compared to other OECD countries, the impacts of socioeconomic status and immigrant background are stronger than average (Fuentes, 2011). Nevertheless, when socioeconomic status is accounted for, migrant-native PISA score gap seems to decrease (Meunier, 2011). For their part, Vellacott and Wolter (2005) have pointed out that, the correlation between educational outcomes and socioeconomic background increases with tracking. The existence of a structural gap between natives and migrants at the end of compulsory school, has been documented in a recent official report from the advisory board of the Swiss government, in terms of education policy (CDIP, 2011).

\footnotetext{
${ }^{1}$ The equivalent of US States or German Länder

${ }^{2}$ The age of tracking varies between 10 and 13 years old. At the beginning of the school year 2011-2012, a reform has been introduced aiming precisely at harmonizing schooling systems across French-speaking cantons, setting the age of tracking at 13 years old.
} 
One striking finding is that, at equal school performance levels, natives are four times more likely than migrants to find a firm offering them an apprenticeship contract. When ending compulsory school, such barriers to entry on the labor market may push migrant students more often toward general education, whenever possible. However, when they do not meet grade requirements, the only remaining alternative - inside the public schooling system - is a transitory solution: one or two year of non-certifying education (what will also be called "remedial education").

Over the last ten years, the number of youngsters engaging in remedial education has been steadily rising, an alarming fact for schooling authorities (CDIP, 2011). One explanation for this increasing popularity is to be found in the private sector: firms are becoming more reluctant to offer apprenticeship (i.e., dual VET) contracts to students just ending compulsory school, as shown by Schweri and Mueller (2007). Their research points out several reasons for this supply-side decline, including: the increasing share of foreign factors of productions (labor and capital) that are not accustomed with the culture of apprentice training, and shifts in industry, whereby the size of traditional apprenticeship-oriented sectors has been declining recently. In addition, some demand-side effects have also been at play; as in many western countries, youngster are increasingly oriented toward academic and general education (Leslie and Drinkwater, 1999).

The migrant population in Switzerland has been deeply affected by a labor-market oriented immigration policy. From the end of World War II to the beginning of the nineties, the government has applied the so called "guest-worker policy". Under such policy, unskilled male workers were actively recruited in South-Western European countries for short-term contracts (in Italy first, then in Spain and, more recently, in Portugal). This resulted in a massive wave of Mediterranean migrants, assigned, generally, to unstable low-paid jobs. However, many of them found their way inside the economic system and managed to secure a job and, consequently, benefit from the family-reunion clause. Nowadays, second- and third-generation Mediterranean children represent an important population inside the schooling system.

Since the middle of the nineties, the government has reoriented its policy towards bilateral agreements with the European Union. The agreement on the Free Movement of Persons, enforced in 2002, was designed - at least partially- to attract more highly skilled migrants and, at the same time, to limit the arrival of relatively unskilled migrants. While certainly attracting highly-skilled professionals from all over Western Europe, this new agreement did not prevent an influx of low-skilled workers and political refugees due to, respectively, on-going family reunions and Eastern-European conflicts (especially in the relatively close-by Balkan region). This recent wave of migrants is, therefore, highly heterogeneous, with respect to skill levels and ethnic composition.

International and national evidence examining the end of compulsory school fit well the theory of social capital, as pioneered by Bourdieu (1986) and Coleman (1988), stating that not only financial and human capital matter, but also a softer, more fungible, form of capital, i.e. social capital. Extending this notion in the context of immigrants, Rumbaut (1998) provides us with an encompassing sociological framework. His typology of migrant 
relies on the fact that, any migrant can be characterized by a distinct set of resources and vulnerabilities: social class resources (financial and human capital); legal status in the destination country (what Rumbaut calls "political capital") and social network, family structure and cohesiveness, i.e. social capital. Obviously, social capital covers access to information channels (Coleman, 1988), which is reflected by an increasingly difficult access to information about the schooling system for more culturally distant migrant groups (see Zhou and Kim, 2006). Consequently, implications of past school choices are imperfectly evaluated among migrant families. We believe that a lack of social capital may be adequately captured by a multidimensional notion of cultural distance. We argue that cultural distance, as measured by nationality, language spoken at home and "tenure" in the local schooling system, play a fundamental role in explaining first upper-secondary track choices, independently of human and financial capital. We find that the influence of cultural distance varies among migrants and is particularly affected by students' abilities, as reflected (although imperfectly) by their middle school track (either high or low). The impact of cultural distance is higher for low-track students, given the limited set of choices generally available to them. In addition, we show that, even when low-track and high-track students are part of the same cohort and the same school, socioeconomic and sociodemographic external effects regarding track choices at the upper secondary do not affect them in the same way.

Our case study is Geneva, a dense urban Canton with the highest share of foreign residential population in Switzerland (in 2010, this share amounted to 39.7\%; OCStat, 2011). Moreover, the relatively small size of the Canton along with an extremely tight housing market, ensure us that school selection bias is not a concern, since children are affected to different middle schools on the sole basis of their home address. Thanks to an exhaustive administrative database, we are able to follow students thorough all their shooling years over a seventeen-year span (1990-2007).

The rest of this paper is structured as follow: the next section shortly describes the schooling system in the canton of Geneva and presents the data used for empirical analysis; section 3 depicts our empirical framework; section 4 exposes our empirical findings, first at the individual level (subsections 4.2 and 4.3) and then at the school level (subsection 4.4). Section 5 concludes.

\section{Local schooling system and dataset}

In Geneva, students enter middle school (lower-secondary level) at the age of twelve; its primary institutional purpose is to orient students and help them choose which type of studies they should embrace after completing their last three years of compulsory education.

Generally speaking, middle school is organized according to a tracking system. At the age of twelve students are grouped conforming to their abilities (as measured by their grades obtained during the previous year). Over the period considered (1990-2007), the system comprises two distinct tracks: a high track (named " $\mathrm{A}$ "), which is considered as 
highly demanding, and a low track (named "B") ${ }^{3}$. It's worth noticing that a majority of students (around $56 \%$ ) finishes middle school in high track, leaving only a smaller percentage of students in low track $(25 \%)$.

For historical reasons 4 three schools are not part of the above-described tracking system and revolve, instead, around a grouping system. The three of them account for around $16 \%$ of students. In the rest of this paper, we will leave those students aside, since they are not directly comparable with tracking students.

Also excluded from the analysis, are immigrants recently arrived in the schooling system and usually sorted in "integration" classes (only less than $2 \%$ of all students), where they primarily learn the local language. Given the special focus of those classes, those students are left aside.

When finishing middle school, high-track students can freely choose which type of education they want to pursue. However, the number of options available to low-track students is considerably smaller, as they are only directly admitted to a reduced number of institutions. Before extending this discussion about transition options any further, let us examine first the upper-secondary level and the main choices offered.

For those pursuing further education (i.e. those not dropping out), the uppersecondary level revolves around five broad types of tracks. The first one, college-bound high school is and has consistently been the most popular choice during the period considered, with on average $48 \%$ of students choosing this track. After obtaining an academic-oriented diploma (the matura), pupils enjoy a direct access to college. It is worth mentioning that the predominance of this track is a specific feature of Frenchspeaking Switzerland, as the German-speaking part is consistently more oriented toward VET. This prevalence is even more marked in the canton of Geneva, where the matura is like a norm for the community, a pass for the "club". Indeed, more than 3 out of 4 natives opt for the academic track (high-track and low-track students confounded). A ratio which has been quite stable during the period considered.

General school is the second type of track and, perhaps unsurprisingly, delivers general knowledge. Besides, minors in four domains 5 are offered, in order to prepare students for tertiary education in selected universities of applied science. Diploma delivered by General School are, generally, not highly valued by the private sector. However, recent reform 5 have rendered general school admission more selective so that, when graduating, students reach the level of competencies required by the corresponding universities of applied sciences. In our data, this track concerns around $11 \%$ of students.

As mentioned in the introduction, Vocational Education and Training (VET) is di-

\footnotetext{
${ }^{3}$ The tracking system prevailing at the beginning of the period (1990-2000), can be thought as roughly equivalent as the one described above. Even though the names and number of tracks differed, the 5 tracks it contained could also be grouped into a 2-track system. Three of them were considered highly demanding (Latin English studies and a more scientific orientation) and one of them was less demanding ("general" orientation).

${ }^{4}$ The main one being that, those schools were, once, part of a pilot study on grouping and decided to keep this system. For more details see Bain et al.(2000).

${ }^{5}$ Namely, communication, visual arts, health and social work.

${ }^{6}$ Applied since 2003.
} 
vided into two sub-tracks: dual apprenticeship and full-time professional schools 7 In all Swiss cantons, students wanting to become an apprentice have to meet two requirements: pass an exam organized by the relevant professional and craft organization, and obtain an apprenticeship contract with a firm. Apprentices usually share their time between school and on-the-job training. After completing vocational schools, full-time VET students (but only holders of a professional matura) may enroll in tertiary education in the consecutive university of applied science. In our data, around $17 \%$ of students selected full time VET education and only $8 \%$ of pupils transited to dual apprenticeship .

Finally, "remedial education" groups all preparatory years to various schools and special structures, designed for students that do not meet other track requirements. It can be seen as an additional non-certifying year (or event two) to a regular curriculum but, at the same time, as a catch-up opportunity. Students encountering difficulties are given a last chance to access an upper secondary education. On average, over the period $7 \%$ of students have transited to a remedial track.

Now that we have examined both sides of the transition, it is interesting to establish the different links between the two. The following discussion assumes that the student finished middle school being promoted $\sqrt{8}$ Transition average percentages, by track, are presented in table 1 . As mentioned, when completing middle school high-track students find themselves in a favorable position, as they are directly admitted to almost all schools listed above. The only exception is dual apprenticeship that, regardless of middle-school grades and track, requires a contract between a firm and an apprentice. Of course, students with better grades are usually more likely to find a firm willing to teach them, but there is no guarantee. Interestingly, once hired by a firm, the corresponding professional school is required by law to enroll an apprentice; schools have no say in the selection process.

For low-track students, the situation is a little bit more complicated: along with remedial education, only general school offers a direct admission. Both full-time vocational education and college-bound high school have set admission requirements, with high school being highly selective

As mentioned before, table 1 illustrates that there exists a certain transition norm, some sort of "first best", and that it differs between high-track and low-track students. High-track students markedly (are able to) favor the academic track, while low-track students tend to favor dual or full-time vocational education.

The database used in this paper is the Geneva Schooling Database (GSD) ${ }^{9}$, compiled and yearly updated by the cantonal schooling administration. The GSD records every child who goes to public and private schools in Geneva from primary to upper-secondary

\footnotetext{
${ }^{7}$ The duration of dual apprenticeship varies between 2 years for a federal "attestation", to 3 to 4 years for a federal certificate, which is the most common upper-secondary diploma held among the workforce. Full-time professional schools deliver different types of diploma: federal attestations (2 years) or certificates (3 years), that are primary obtained by middle-school low-track students, and professional maturas (4 years), usually obtained by middle-school high-track students, allowing them to access directly the corresponding universities of applied sciences.

${ }^{8}$ Which corresponds to a general average of at least 4 out of 6 .

9"Base de données scolaires"
} 
Table 1: Transitions from lower to upper-secondary level by track 1990-2007 (in percent)

\begin{tabular}{lccccccc}
\hline & $\begin{array}{c}\text { College-Bound } \\
\text { High School }\end{array}$ & General School & Full Time VET & Dual VET & Remedial & Drop Out & Total \\
\hline A students & 68.59 & 4.56 & 17.07 & 3.8 & 1.81 & 4.17 & 100 \\
$\mathrm{~N}$ & $21^{\prime} 858$ & $1^{\prime} 452$ & $5^{\prime} 439$ & $1^{\prime} 212$ & 578 & $1^{\prime} 328$ & $31^{\prime} 867$ \\
\hline B students & 1.76 & 26.2 & 17.29 & 18.06 & 24.14 & 12.55 & 100 \\
$\mathrm{~N}$ & 243 & $3^{\prime} 609$ & $22^{\prime} 382$ & $2{ }^{\prime} 487$ & $33^{\prime} 325$ & $1^{\prime} 728$ & $133^{\prime} 774$ \\
\hline
\end{tabular}

Source: Geneva Schooling Database (2007)

leve ${ }^{10}$ We could access data from 1990 up to 2007, i.e. data for seventeen cohorts of students. In order to perform the analysis, the GSD was trimmed to get rid of duplicates and suspicious cases ${ }^{11}$

Our dependent variable only records transitions from the last year of public middle school to the fist year in any upper-secondary school, including drop out cases. Note that this definition excludes repeating cases, as only first transitions are taken into account. In addition, as already mentioned, we only keep pupils transiting either from high-track or low-track and exclude grouping cases for comparability reasons. Finally, for our model to capture school effects accurately, we run the analysis exclusively on students who stayed in the same school during all their middle-school years ${ }^{12}$, and on schools who existed during the whole period 13

Over the period, our dependent variable records around 45’500 transitions, from fourteen different middle schools.

\section{Empirical framework}

As discussed previously, we expect that the great majority of students are not confronted to a binary choice, nor a choice that can be ordered. Students can choose between different transition options, depending on their track and grades. Suppose for now that is there no tracking, but only minimum grades requirements. Those requirements vary with each of the $j$ transition alternatives $(j=1$ to $J$ ) faced by a student $i$ belonging to cohort $t(t=1$ to $T)$ and to middle-school establishment $s(s=1$ to $S)$. Suppose also that, preferences for an alternative $j$ can be represented by an Additive Random Utility function utility $U$, such that:

$$
U_{i s t j}=V_{i s t j}+\varepsilon_{i s t j}
$$

where $V_{i s t j}$ is the deterministic component of the utility and $\varepsilon_{i s t j}$ is the random or idiosyncratic component. If the cost of effort to reach a minimum grade requirement for

\footnotetext{
${ }^{10}$ But compulsory private education concerns less than $10 \%$ of all children.

${ }^{11}$ Namely, cases where the date of birth changed over the years, creating discrepancies with the age variable.

${ }^{12}$ Which led us to exclude around 3000 students.

${ }^{13}$ Three middle schools that opened up only recently were, therefore, excluded from the analysis
} 
transition $j$ is $c_{i s t}$, the net utility obtained when opting for alternative $j$ is then:

$$
N U_{i s t j}=V_{i s t j}+\varepsilon_{i s t j}-c_{i s t j}
$$

with $c_{i s t j}>0$. The deterministic component of the net utility obtained from any alternative is a function of student individual and family-related characteristics represented by the vector $\mathbf{x}$. However, because peers can not only potentially affect student schooling performance ${ }^{14}$ but also influence transition choices, we therefore assume that individual preferences may vary between school establishments and between cohorts, such that: $V_{i s t j}=\lambda_{j}^{\prime} \mathbf{x}_{i}+\gamma_{j} s_{i}+\xi_{j} t_{i}$.

Besides peer effects, the relative autonomy of establishments (which characterizes the lower-secondary level in Geneva) can generate a distribution of individual costs, $c_{i s t j}$, independent of a student individual and family-related characteristics for two reasons: first, theoretically, social capital is not necessarily correlated with human and financial capital; second, each school management react to external pressure (new government rules and public laws) differently. This may be the case either because the application of the central positive discrimination policy is partially school-specific, or because there exist differences in terms of teachers quality, given the relative policy space granted to middle schools. Thus, we assume the cost of reaching the minimum grade required for each of the $J$ alternatives to depend on the same variables than the deterministic component of net utility, such that: $c_{i s t j}=\delta_{j}^{\prime} \mathbf{x}_{i}+\zeta_{j} s_{i}+\psi_{j} t_{i}$.

We observe $y_{i s t j}$ if outcome $j$ has the highest net utility among all alternatives for individual $i$ belonging to cohort $t$ and school establishment $s$. In other terms:

$$
\begin{aligned}
\operatorname{pr}\left(y_{i s t}=j\right) & =\operatorname{pr}\left(N U_{i s t j}>N U_{i s t k}, \text { for all } k \neq j\right) \\
& =\operatorname{pr}\left(N U_{i s t j}-N U_{i s t k} \leq 0, \text { for all } k \neq j\right) \\
& =p r\left(\varepsilon_{i s t j}-\varepsilon_{i s t k} \leq V_{i s t j}-c_{i s t j}-V_{i s t k}+c_{i s t k}, \text { for all } k \neq j\right)
\end{aligned}
$$

From (5), it follows that the type of discrete choice model depends on the assumption regarding the joint distribution of the errors. Assuming errors are iid and follow a standard Gumbel distribution, with density $f\left(\varepsilon_{j}\right)=e^{-\varepsilon_{j}} \exp \left(-e^{-\varepsilon_{j}}\right)$, it can be shown that (5) leads to:

$$
\operatorname{pr}\left(y_{i s t}=j\right)=\frac{e^{\left(V_{j}-c_{j}\right)}}{1+e^{\left(V_{1}-c_{1}\right)}+e^{\left(V_{2}-c_{2}\right)}+\ldots+e^{\left(V_{J}-c_{J}\right)}}
$$

which is a reduced form multinomial logit model (McFadden, 1973) where $\left(V_{j}-c_{j}\right)=$ $\beta_{j}^{\prime} \mathbf{x}+\alpha_{j} s+\eta_{j} t=\left(\lambda_{j}-\delta_{j}\right)^{\prime} \mathbf{x}+\left(\gamma_{j}-\zeta_{j}\right) s+\left(\xi_{j}-\psi_{j}\right) t$

One important insight gained from this discussion is that the multinomial logit model relies on the assumption that errors are independent. However this assumption is likely to be violated if two (or more) alternatives are similar, as in the classical red bus/blue bus example 15 Formally, the Independence of Irrelevant Alternatives (IIA) states that

\footnotetext{
${ }^{14}$ See, for example, Angrist and Lang (2004).

${ }^{15}$ For a more extended discussion, see Greene 2011) and Cameron and Trivedi 2005
} 
the introduction of a new alternative will not impact the choice between existing alternatives, i.e. "the odds do not depend on other alternatives that are available" (Long and Freese, 2005). We acknowledge this weakness but choose to use this model nevertheless. As discussed in the previous section, we motivate this choice by arguing that the six transition alternatives are sufficiently dissimilar (at least, in terms of requirement and labor market opportunities) and are, therefore, unlikely to suffer from a correlation problem.

If the lower-secondary level is characterized by tracking and minimum grade requirements that vary by track, for each transition alternative $j$ (as in our case, where admission criteria are higher for low-track students for some $j$ ), the estimated vector of parameters $\beta, \alpha$ and $\eta$ will be conditional on the middle-school track. Hence, we estimate a reduced form multinomial logit model separately for low-track (B) and high-track (A) students.

\section{Empirical findings}

\subsection{Variable description}

In addition to traditional controls, our choice of independent variables aims at controlling for the different types of capital already mentioned: human and financial, political, and social.

Classical controls include: gender ("girl") and a performance indicator ("late"), defined as, whether or not, the student has repeated -at least- one year in middle school.

Human and financial capital are both proxied by the combined socioeconomic status of both parents ("directors" "blue collars" "self employed" and "miscellaneous/NA"), where the contrast is white-collar workers. This variable is carefully built by the schooling administration, based on the yearly information provided by parents, to accurately reflect the socioeconomic environment of the child.

Social capital is captured, or at least proxied, by a set of variables. First, family structure is taken into account, as one-parent families are able to provide less social capital for their children (Coleman, 1988). The "conventional family" dummy variable has a one value when a student lives with both parents. The age at arrival inside the schooling system reflects the idea that, more time spent inside the system makes integration and assimilation easier (Hirschman, 2001). In parallel, long-time migrants usually have a better and more extended social network, i.e. more social capital. We split the continuum of possible school ages at arrival into five different categories: a first group contains all students either born in Geneva or arrived before the beginning of preschool, i.e. before four years old. The second category encompasses all children arrived before six years old, which, in fact, corresponds to the beginning of primary school. Pupils arrived during primary school are split into two groups: those arrived before seven years old and those arrived before eleven ${ }^{16}$. Our last category regroups students arrived during middle school, i.e. before fifteen. Children who spent all their school years in Geneva are the reference

\footnotetext{
${ }^{16}$ The rationale behind this splitting is that, formally, primary school is divided into two cycles, called elementary and intermediate.
} 
$\operatorname{group}^{17}$

Social capital is more easily acquired when the language spoken at home and in the destination country coincide (Rumbaut, 1998). This phenomenon is captured by the "non-french speaker" dummy variable. It takes the value 1 , if the home language of the child is not French. Finally, both origin and nationality are accounted for. Due to data constraints and to have a sufficient number of observations in each group, nationalities are sorted into five broad groups; Swiss is taken as the reference case. The category "Mediterraneans" encompasses students from Italy Portugal and Spain, reflecting the first wave of migrants in Switzerland. The EU-27 group contains all other EU 27 and EFTA countries, except, of course, for the three just mentioned. Balkans and Turks pupils are either from Turkey or from former Yugoslavia 18 , all other nationalities are grouped under "Others". This later category includes African, Asian, Middle Eastern or American students and is, therefore, relatively heterogeneous. A table of descriptive statistics concerning the composition of the different nationality groups can be found in the appendix (table A.1).

Regarding origin, in about $77 \%$ of cases it coincides with nationality (see appendix table A.2. While we can fully control for students' nationality with the grouping aforementioned, due to data constraints we only introduce a dummy "foreign origin" as an additional control. This variables takes a value one for all students from any other country of origin than Switzerland 19

Unfortunately, no variable allows us to properly control for the family's political capital. However, since our nationality groups reflect the various migration waves, as defined by their period of arrival, political capital is, at least partially, embedded in nationality dummies.

A table with selected descriptive statistics for all our independent variables (by middle-school track) can be found in appendix table A.3. From table A.3, it appears that populations of students are clearly different between tracks. One striking - and unsurprising - fact is that migrants make a higher proportion of low-track students, as do blue collars. Conversely, natives and directors make a larger proportion of high-track students. In addition, variables reflecting social capital (non-french speaker, conventional family, foreign origin) are all found in greater proportions among low-track students, reflecting a generally higher level of cultural distance in this track.

\subsection{Estimation results}

As justified in section 3, we estimate a multinomial logit model on low-track and hightrack students separately, including year- and school-fixed effect:20 Estimation results

\footnotetext{
${ }^{17}$ Specifications including an interval variable and the addition of a square term have also been tested.

${ }^{18}$ Namely: Albania, Bosnia-Herzegovina, Croatia, Kosovo, Macedonia, Montenegro and Serbia.

${ }^{19}$ Note that this later case also includes Swiss students coming from abroad.

${ }^{20}$ We choose school effects over neighborhood effects because, as stated in Arum(2000 "models of neighborhood effects on educational outcomes (...) fail to incorporate measures of school characteristics thus implicitly assume that either schools vary solely as a function of demographic and organizational characteristics of neighborhood settings (...) or that variation in schooling is inconsequential and in-
} 
are presented in tables 2 and 3 . In order to avoid confusion, we present results as marginal effects; since numbers are already in percent, a coefficient can be interpreted as the change in transition probability induced by a discrete change in a given variable, all else being equal. To give the reader a sense of the variability associated with either time or schools, we also report minimum and maximum normalized estimated marginal effect: ${ }^{21}$ for, respectively, school- and year-fixed effects. These effects will be largely discussed in section 4.4 .

First and for both types of students, social capital matters independently from human and financial capital: variables reflecting social capital appear significant alongside socioeconomic status. Lower-bound estimated marginal impacts resulting from a lack of social capital range, from $-14.7 \%$, to $+6.6 \%$. Those numbers correspond to the addition of marginal effects found for "blue collars" (the most disadvantaged socioeconomic category), "non-french speaker" and "foreign origin", to which is then subtracted the "conventional-family" effect. Nationality dummies are not taken into consideration here but would be, if the goal was to reflect social capital of a certain type of migrant.

The biggest impact of social capital is found for high-track students, concerning the transition probability to college-bound high school. This result fits well the Bourdieusian view of cultural capital and education reproduction, as summarized in Driessen (2001): schools are organized so as to fit the need of the dominant group and presuppose a specific amount of cultural capital ("particular codes and values", p. 515), in order to benefit from the material. In this perspective, it is not surprising that a lack of social capital affects mainly the most academically-demanding transition option.

In both sets of results, family structure appears significant, increasing transition probabilities to each track's norm, respectively, college-bound high school and full-time VET. Nevertheless, results differ substantially between high-track and low-track students.

For high-track students, the largest marginal effect is associated with the "late" variable. A drop in performance, i.e. repeating one year, has important consequences. It seems to send an institutionally negative signal, so that, when post-compulsory tracking is decided, chances of access to the academic track are strongly reduced $(-30 \%)$. Similarly, being late increases the likelihood to transit to full-time VET by $18 \%$.

Another variable having fairly large effects, is gender: being a girl increases one's probability to follow the academic path by $11 \%$ and decreases chances to enroll into fulltime VET by approximately the same amount. This reflects a standard result showing differences in aspirations between boys and girls (Gilbert et al., 2010), that will be subsequently reflected through horizontal labor market segregation 22 Parental human and financial capital seem to influence almost all transitions, but largest effects are observed for the academic path.

significant. If schools, however, vary as a result of (unmeasured) political and institutional factors, and variation in the structure of schooling affects student achievement, then much of the research on how neighborhood affect educational outcomes has been characterized by significant omitted-variable bias" (p. 401).

${ }^{21}$ Estimated time- and school-fixed effects are just normalized using their respective weighted means. See, for example, Krueger and Summers $(1988)$ for an application to industry wage premiums.

${ }^{22}$ See Loutfi (2001) for a review 
Results on low-track students are quantitatively and qualitatively different. At first glance, fewer variables appear significant and effects are generally of lower magnitude. Interesting outcomes seem to revolve around three axis: gender, parental human and financial capital, and social capital, including dummies reflecting the age at arrival.

First and unsurprisingly, gender still affects all transition probabilities, but largest and opposite effects are found for general school and dual VET (with +15 and $-10 \%$ respectively).

Interestingly, parental human and financial capital does appear to play a major role : only children from the highest socioeconomic background ("directors") are more oriented toward full-time vocational schools, the "first best" for this track. Besides, dropouts appear more frequent. This a priori counter-intuitive result (after all, why would children from directors drop out more often, all else being equal) might be explained by the wider educational options available to those children. If the first best is not available, exiting the public system and opting for a private education is preferred.

Third, worth pointing out are the different impacts of variables reflecting social capital. Not being a native French speaker influences significantly transition probabilities, lowering the chances of a student to transit to the apprenticeship system $(-2.6 \%)$. This might reflect, either a labor market issue, since non-native speakers might find it harder to get an apprenticeship contract, or a greater difficulty for non-native speaker to successfully pass the craft exam.

Concerning nationality groups and compared to natives, impacts vary considerably from one group to another. First first-wave Mediterranean migrants display relatively similar transition profiles to Swiss, as reflected by the small number of significant marginal effect and their relatively low magnitude. On the other hand, latest-generation migrants (Balkans and Turks or Others) exhibit singular transition patterns. We explore this result in greater depth in the following section. 
Table 2: Multinomial logit regression on high-track (A) students, marginal effects in percent

\begin{tabular}{|c|c|c|c|c|c|c|}
\hline & High School & General School & FT VET & Dual VET & Remedial & Drop out \\
\hline observed prb. & 68.59 & 4.56 & 17.07 & 3.8 & 1.81 & 4.17 \\
\hline girl & $11.54^{* * *}$ & $2.72^{* * *}$ & $-10.90^{* * *}$ & $-1.90 * * *$ & $-0.77^{* * *}$ & $-0.69 * * *$ \\
\hline late & $-29.71^{* * *}$ & $7.25^{* * *}$ & $13.01^{* * *}$ & $4.60^{* * *}$ & $2.21^{* * *}$ & $2.63^{* * *}$ \\
\hline arrival: $4-5$ у. о. & -1.43 & 0.25 & -0.21 & 0.01 & -0.09 & $1.48^{* *}$ \\
\hline arrival: $6-7$ у. о. & -0.3 & $1.44^{*}$ & $-3.05^{* *}$ & -0.11 & -0.38 & $2.41^{* * *}$ \\
\hline arrival: 8-11 у. о. & $-4.26 * * *$ & 0.16 & 0.51 & -0.09 & 0.21 & $3.48^{* * *}$ \\
\hline arrival: $12-14$ у. о. & $-12.98 * * *$ & $3.69^{* * *}$ & 1.04 & 0.75 & 0.53 & $6.97^{* * *}$ \\
\hline directors & $9.08 * * *$ & $-1.92^{* * *}$ & $-6.48^{* * *}$ & $-1.83^{* * *}$ & $-0.62 * * *$ & $1.77^{* * *}$ \\
\hline self employed & $-8.69 * * *$ & $1.23^{* *}$ & $6.12^{* * *}$ & $1.55^{* * *}$ & 0.07 & -0.27 \\
\hline blue collars & $-13.17 * * *$ & $1.83^{* * *}$ & $7.29 * * *$ & $3.11^{* * *}$ & $0.77^{* * *}$ & 0.17 \\
\hline misc./NA & $-7.04^{* * *}$ & $3.00^{* * *}$ & 1.11 & $1.30^{*}$ & $1.38^{* *}$ & 0.26 \\
\hline conventional family & $3.84^{* * *}$ & $-1.02 * * *$ & $-1.35^{* *}$ & 0.06 & -0.27 & $-1.26^{* * *}$ \\
\hline non-french speaker & $4.71^{* * *}$ & $-1.70^{* * *}$ & $-2.21^{* * *}$ & $-1.12^{* * *}$ & -0.18 & 0.5 \\
\hline of foreign origin & $-2.39^{* *}$ & 0.49 & 0.21 & 0.32 & 0.14 & $1.23^{* * *}$ \\
\hline Balkans \& Turks & $-5.16^{* *}$ & 0.96 & $5.48^{* * *}$ & $-1.25^{* *}$ & 0.79 & -0.82 \\
\hline EU27 & $4.01^{* * *}$ & -0.25 & $-2.77^{* * *}$ & $-2.14^{* * *}$ & -0.1 & $1.25^{* *}$ \\
\hline Mediterraneans & $-10.00^{* * *}$ & $2.06^{* * *}$ & $4.66^{* * *}$ & -0.35 & $1.08^{* * *}$ & $2.54^{* * *}$ \\
\hline Others & $3.74^{* * *}$ & $-1.07^{* * *}$ & $-2.98^{* * *}$ & $-2.57^{* * *}$ & $0.90 * *$ & $1.98^{* * *}$ \\
\hline year min & $-4.43^{* * *}$ & $-1.68 * * *$ & $-7.74^{* * *}$ & $-1.03^{* * *}$ & $-1.42^{* * *}$ & $-1.01^{*}$ \\
\hline year max & $8.37^{* * *}$ & $1.98^{* * *}$ & $1.93^{* * *}$ & $0.48^{* *}$ & $0.17^{* *}$ & 0.00 \\
\hline school min & $-6.72^{* *}$ & $-1.96^{* * *}$ & $-7.89 * * *$ & $-1.93^{* * *}$ & 0.00 & $-0.22^{*}$ \\
\hline school max & $8.92^{* * *}$ & $1.61^{*}$ & $4.31^{*}$ & 0.00 & $0.54^{* * *}$ & $1.19^{* * *}$ \\
\hline
\end{tabular}

Number of observations

$31^{\prime} 635$

Legend: * $0.10 * * 0.05 * * * 0.01$

Notes: dependent variable is the transition choice. Year and school dummies are included; standard errors are computed using the delta method.

All variables are held at their sample average and factor variables handled consistently. 
Table 3: Multinomial logit regression on low-track (B) students, marginal effects in percent

\begin{tabular}{llllllc}
\hline & High School & General School & FT VET & Dual VET & Remedial & Drop out \\
\hline observed prb. & 1.76 & 26.2 & 17.29 & 18.06 & 24.14 & 12.55 \\
\hline girl & $0.46^{* * *}$ & $15.98^{* * *}$ & $-7.13^{* * *}$ & $-10.18^{* * *}$ & 0.02 & 0.85 \\
late & -0.14 & 0.06 & -0.9 & 1.2 & -0.35 & 0.14 \\
arrival: 4-5 y. o. & 0.12 & -0.75 & -2.26 & 2.07 & 1.06 & -0.23 \\
arrival: 6-7 y. o. & 0.17 & $-3.36^{*}$ & $-3.68^{* *}$ & $4.33^{* *}$ & -1.58 & $4.13^{* *}$ \\
arrival: 8-11 y. o. & -0.29 & $-3.38^{* *}$ & $-4.89^{* * *}$ & $3.64^{* *}$ & 1.69 & $3.22^{* *}$ \\
arrival: 12-14 y. o. & 0.14 & $-7.02^{* * *}$ & -2.76 & 2.47 & 2.02 & $5.15^{* *}$ \\
directors & 0.51 & -0.27 & $5.25^{* * *}$ & $-5.08^{* * *}$ & $-4.24^{* *}$ & $3.83^{* *}$ \\
self employed & -0.35 & -1.71 & 0.54 & 1.2 & -0.53 & 0.85 \\
blue collars & $-0.59^{* * *}$ & 0.05 & -0.76 & $3.42^{* * *}$ & 0.4 & $-2.53^{* * *}$ \\
misc./NA & -0.13 & -1.14 & $-4.70^{* * *}$ & 0.92 & $3.93^{* *}$ & 1.13 \\
conventional family & -0.03 & 0.46 & $3.38^{* * *}$ & 0.36 & -0.95 & $-3.23^{* * *}$ \\
non-french speaker & $0.61^{* * *}$ & $-4.53^{* * *}$ & $3.78^{* * *}$ & $-2.59^{* *}$ & $5.04^{* * *}$ & $-2.31^{* *}$ \\
of foreign origin & $-0.44^{* *}$ & $2.97^{* *}$ & -1.6 & -0.85 & $-2.54^{* *}$ & $2.46^{* *}$ \\
Balkans \& Turks & $0.94^{*}$ & $-3.54^{*}$ & 2.12 & $-6.38^{* * *}$ & $8.92^{* * *}$ & -2.06 \\
EU27 & $1.70^{* *}$ & -0.51 & 0.11 & $-7.98^{* * *}$ & 2.45 & $4.23^{* *}$ \\
Mediterraneans & 0.03 & 0.45 & $-3.78^{* * *}$ & -0.86 & 1.79 & $2.37^{* *}$ \\
Others & $1.83^{* * *}$ & 0.54 & 1.52 & $-14.80^{* * *}$ & $11.66^{* * *}$ & -0.75 \\
\hline year min & $-0.4^{*}$ & $-20.88^{* * *}$ & $-6.02^{* *}$ & $-10.4^{* * *}$ & $-7.71^{*}$ & 0.00 \\
year max & $0.79^{* * *}$ & 0.00 & $7.86^{* * *}$ & $4.38^{*}$ & $14.26^{* * *}$ & 0.00 \\
school min & $-1.8^{*}$ & 0.00 & $-3.91^{* * *}$ & $-5.79^{* * *}$ & 0.00 & $-0.5^{*}$ \\
school max & $4.12^{* * *}$ & $2.45^{* *}$ & 0.00 & $1.27^{* *}$ & $3.61^{* * *}$ & $7.58^{* * *}$ \\
\hline
\end{tabular}

Number of observations

$13^{\prime} 620$

Legend: * $0.10 * * 0.05 * * * 0.01$

Notes: dependent variable is the transition choice. Year and school dummies are included; standard errors are computed using the delta method.

All variables are held at their sample average and factor variables are handled consistently.

\subsection{Age at arrival}

In this subsection, we discuss the impact of the age at arrival on different types of profile.

As suggested by marginal effects, the impact of the age at arrival differs for each track. Concerning high-track students, time spent inside the schooling system matters especially with respect to college-bound high school: students arrived later than eight years old exhibit a lower transition probability to the academic track, while their probability to drop out increases. Other transition options are not affected. This result reflects a certain polarity inside the schooling system; if high-achieving students are somehow prevented from accessing high school (their track's "first best"), they rather choose to exit the public educational system, than transit to another track.

In order to explore the interactions between the age at arrival and nationality groups, we compute transition probabilities associated with each category of those two variables, for two distinct sub-populations: high-track girls and low-track boys. Indeed, we argue 
that those two types of students represent extremes in terms of post-compulsory school transitions, as high-track girls transit to college-bound high school $74 \%$ of the time (more than the average rate of $68.6 \%$ for this track) and low-track boys transit disproportionally more (20-22\%) to vocational education compared to girl peers (12-13\%).

Figure 1 presents the evolution of transition probabilities to college-bound high school and to full-time VET (and their corresponding 95\% confidence intervals), the two most common choices for high-track female students. This probability is relatively high for all nationality groups and stays roughly constant for all children arrived before twelve years old, confirming the existence of a certain norm, equally affecting almost all high-track students. Compared to Swiss students, only Mediterraneans seem to start with a slight disadvantage, their transition probability being around $10 \%$ lower from an early age and on.

On the other hand, low-track students do seem to benefit from some sort of systemic experience. This experience, or rather the lack thereof, affects particularly transitions to dual VET and to a remedial track. For those later two, we are interested in investigating if the age at arrival plays a different role depending on the region of immigration. For this purpose, we compute transition probabilities associated with each category of age at arrival; those probabilities and their corresponding $95 \%$ confidence intervals are presented in figure 2

First, transition profiles of Mediterranean and Swiss pupils are remarkably similar and for those students, transiting to a remedial track is always significantly less likely than opting for dual VET. This may reflect an assimilation pattern consistent with the assimilation theory (Hirschman, 2001) and a high amount of social capital. Those children are at ease inside the schooling system and, compared to other migrants, succeed more often in finding an apprenticeship contract, thereby avoiding remedial education, when they do not reach grade requirements to integrate either a general school or a fulltime vocational school. However, recent migrants are disproportionally more oriented toward remedial education, even after controlling for individual and familial characteristics (see tables 2 and 3). For those students, around one third of the time, the end of compulsory school rhymes with an additional non-certifying year, while controlling for all other characteristics.

Migrants grouped under "Others", i.e. African, American or Asian migrants, display an interesting profile. For this group, the probability of transiting to a remedial track is always significantly higher than transiting to dual VET. This later finding is extremely difficult to explain but one general comment relates to the phenotypic difference between those students and natives: of all the nationality groups under consideration, this group "others" is the most likely to stand out as "immigrants", with a proportion of African greater than $50 \%$ among low-track male students (while the same share amounts to $30 \%$ for high track students). This, in turn, may trigger some sort of labor-market discrimination based on race. 
Figure 1: Influence of the age at arrival on transition probabilities to College-bound high school and full-time VET, for high-track female students

Swiss

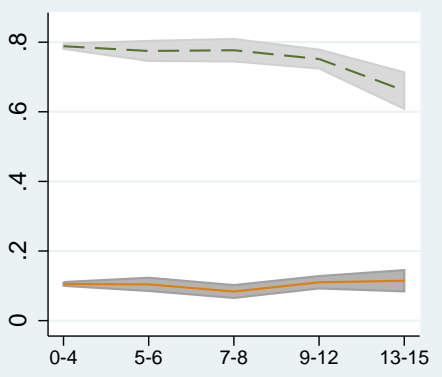

Mediterraneans

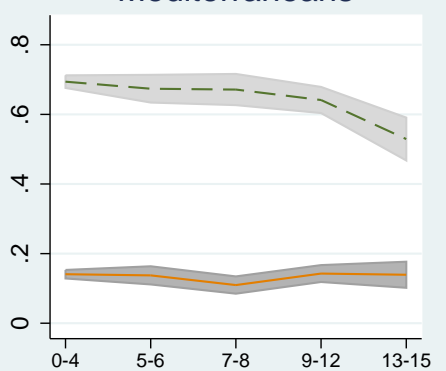

Balkans \& Turks

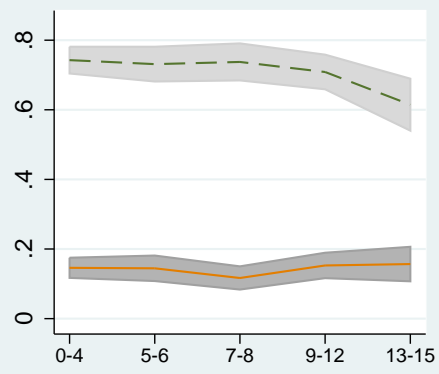

Others

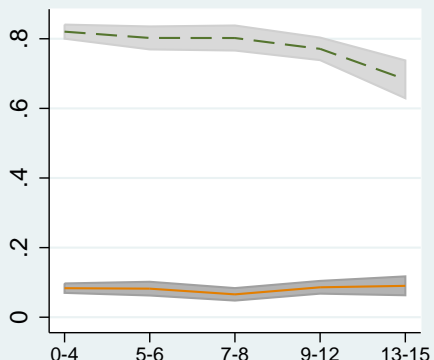

EU27

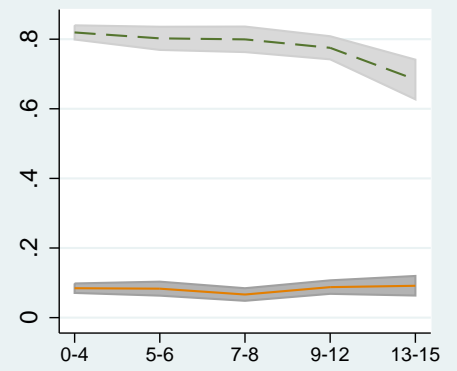


Figure 2: Influence of the age at arrival on transition probabilities to dual VET and remedial education, for low-track male students

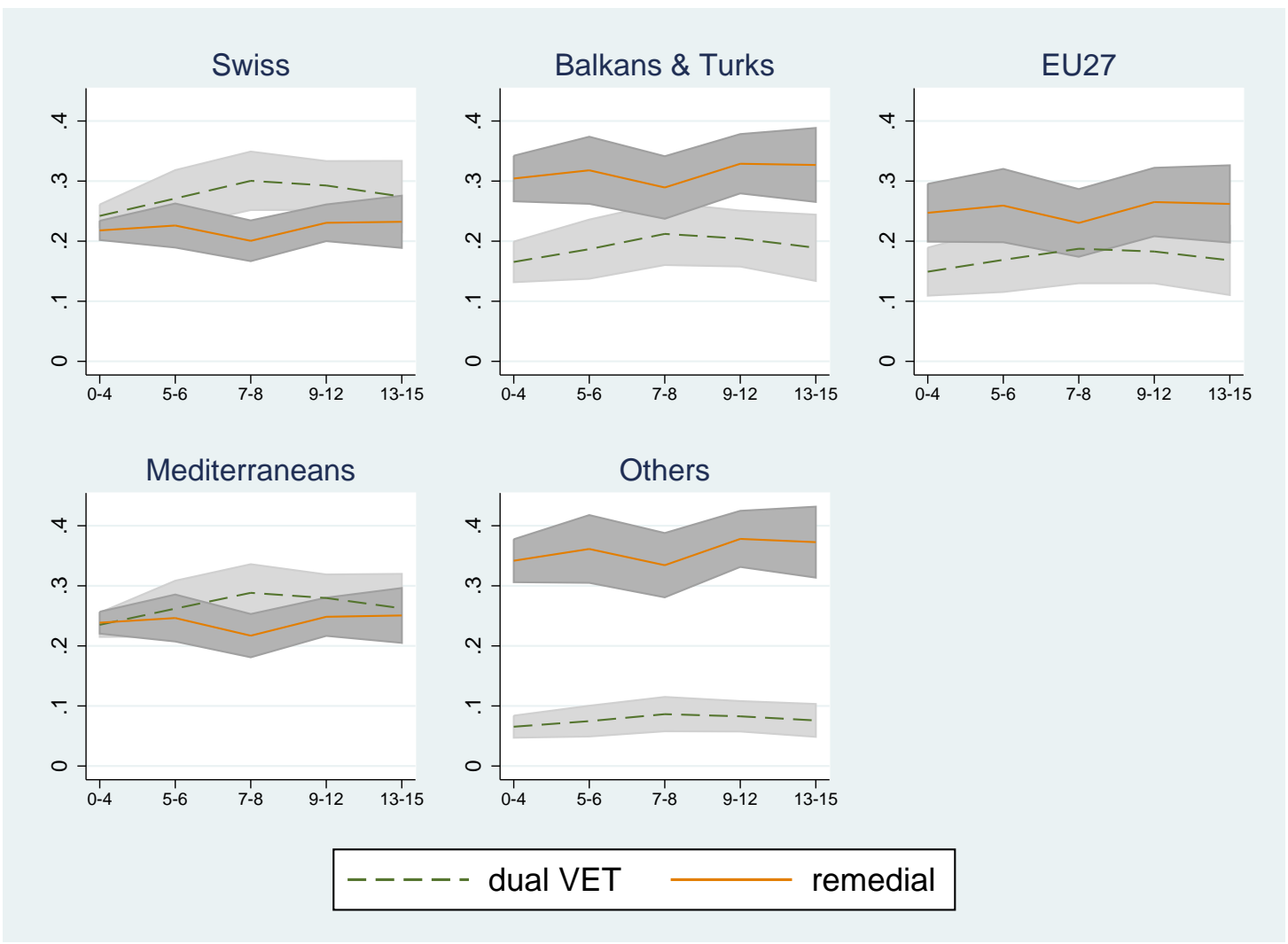

\subsection{School composition}

In this section, we deepen the analysis and try to understand how the structural composition of a school population can affect students transition probabilities, independently of individual and family-related characteristics. We address two distinct empirical questions: how much do differences in school populations (as expressed by their socioeconomic and sociodemographic composition) explain school yearly marginal effects (i.e., the fraction of fitted probabilities that are not explained by individual and familial characteristics), and whether such composition effects differ between low-track and high-track students.

Previously, we have discussed how belonging to a certain sociodemographic and socioeconomic group affects post-compulsory transitions. Marginal effects pointed out that being a repeater has a huge effect on the probability to transit to college-bound high school, the high-track students' first choice. In section 4.3, we have highlighted notable differences between high-track and low-track students, particularly in terms of ethnicity group (measured through nationality and "tenure" in the local schooling system). Together, these results suggest two things: first, social interactions generate bipolar effects 
on student transition probabilities, depending on the within-school group a student belongs to; second, tracking is central to understand how social interactions distort human capital formation, through inefficiencies due, for instance, to statistical discrimination (what Manski (2000) defined as expectation interactions). In this case, empirical consistency requires the following condition to be met: if statistical differences exist between low-track and high-track students at the individual level, and that these differences depend on ethnicity groups, then such differences should also exist when looking at students' affiliation, i.e. the schools. If such a condition is fulfilled, it would support the idea that (middle-school) tracking induces negative effects associated with population heterogeneity.

Estimated time- and school-specific effects on transition probabilities are relatively large for both tracks (see tables 2 and 3). There is thus space for panel regression analysis. To do so, we use the two previously fitted multinomial logit models to compute time-school specific (marginal) effects ${ }^{23}$, for low-track and high-track students separately. These two sets of time-school specific effects are first normalized 24 and then regressed on variables capturing structural differences existing between schools, in our case the socioeconomic and sociodemographic composition of their respective students populations.

Formally, let $\hat{\mu}_{s t j}^{A, B}$ be the vector of normalized estimates of time-school-fixed effects associated with alternative $j$, for either low-track (B) or high-track (A) students. The estimated equation is therefore alternative and track specific, such that:

$$
\hat{\mu}_{s t}^{A, B}=\rho_{0}^{A, B} \bar{p}_{\text {girls }}+\sum_{m=1}^{m=4} \rho_{m}^{A, B} \bar{p}_{\text {socioeco }}+\sum_{r=1}^{r=4} \rho_{r}^{A, B} \bar{p}_{\text {nationality }}+\sum_{t=1}^{t=T} \xi_{t}^{A, B} t+\epsilon_{s t}^{A, B}
$$

where $\bar{p}_{\text {girls }}, \bar{p}_{\text {socioeco }}$ and $\bar{p}_{\text {nationality }}$ are, respectively, the average proportions of girls, the average proportions of the various socioeconomic status and of the several nationality groups, all measured at the establishment level over the Tyears. The last two terms represent, respectively, year-fixed effects that are common to all establishments and an error term which, by construction, captures school-specific effects and a "true" error term. Therefore, equation (7) corresponds to what is generally known as a "between" panel model, where, first, the estimated error term reflects variations within school establishments; second, estimated time effects capture both exogenous shocks and institutional changes associated with educational reforms affecting all schools (e.g., an alternative-specific change in grade requirements).

Regression results are presented in table 4 . Columns labeled "A-B" report test result on the significance of the difference between a given $\mathrm{A}$ and a given $\mathrm{B}$ coefficient. The significance level is set at $95 \%$.

\footnotetext{
${ }^{23}$ Since we have 14 schools and 17 years, the total number of observation for each transition alternative (and for each track) is 238 .

${ }^{24}$ For the two middle-school tracks and each of the six transitions, we normalize the estimated effects by using the number of students per school and per year, as weights. The normalized estimates of timeschool-fixed effects can, therefore, be interpreted as deviations from the weighted mean associated with each of the possible transition and middle-school track.
} 
Estimated parameters can be interpreted as quasi-elasticities, i.e. how much does a time-school-specific effect vary, when a certain (average) school proportion increases by one percent, compared to the weighted Cantonal average. However, caution is needed when interpreting the sign and size of such estimates. Focusing, for example, on estimates associated with the various nationality groups, we observe that, a relatively higher proportion of students from Balkans and Turkey, in a given school, increases the probability of all high-track students in that school to transit to college-bound high school (denoted simply as "high school" in the table), but, at the same time, reduces it for low-track students. Similarly, a higher proportion of Balkan and Turk pupils reduces the probability to transit to dual vocational education (i.e. apprenticeship) of all students in that school, but with magnitudes differ between high-track and low-track students. There are, undoubtedly, different types of social interactions (i.e. endogenous and contextual interactions) and correlation effects at play here, but we are simply not able to disentangle them.

Nevertheless, for both tracks, it clearly appears that estimated time-school-specific effects are largely explained by structural differences existing between schools, regarding their students population 25 , Transition alternatives "Remedial" and "Drop out" appear more sensitive to school-specific changes, in the light of the low R-squared associated with these two options. Our results confirm the idea that, even if low-track and high-track students share the same school, they clearly face different socioeconomic and sociodemographic external effects on their transition probabilities.

\footnotetext{
${ }^{25}$ Common time effects do not explain much, as confirmed by the results obtained, when omitting year-fixed effects (not reported here).
} 


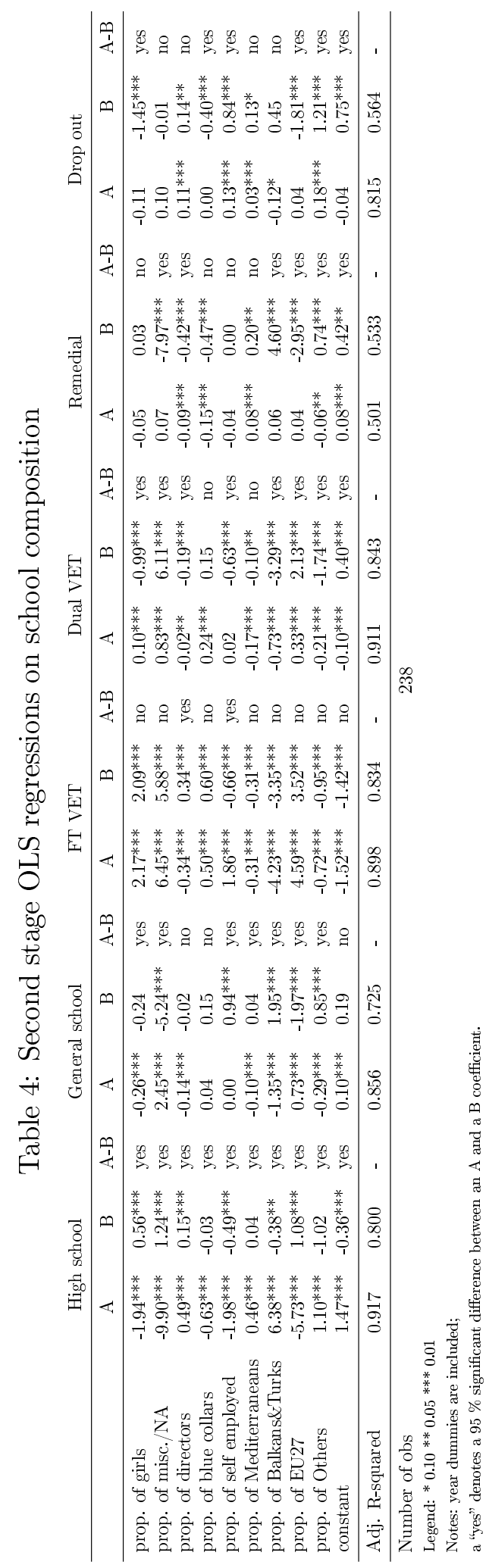




\section{Conclusion}

In this paper, we have examined migrant integration into the Swiss schooling system, as expressed by their track choice at the upper-secondary level, using data for Geneva over the period 1990-2007. Since choices are constrained by middle-school track, we estimated two multinomial logit models, after grouping all transition choices into six different categories. Marginal effects suggested that social capital does, indeed, play a role in determining school choices and does so for both high-achieving and low-achieving students. Relative effects imply that social capital could explain - in absolute value around one quarter (more than a third) of the observed probability to transit to collegebound high school (full-time VET), for high-track students. A lack of social capital particularly affects transition probability to the academic track for high-track students, probably where the "hidden curriculum" plays a greater role (Driessen, 2001).

Integration into the schooling system depends on the migration wave and, to a much lower extent, on the time spent inside the schooling system. First-wave migrant students are, ceteris paribus, expressing track choices close to natives, while differences in transition patterns are more marked for more recent migrants. We shed light on this result using again the theory of social capital. Early migrants have had time to build networks, access information and create an "ethnic community" (Zhou and Kim, 2006), that will support them, and help them assimilate and success in the destination country.

As a case study, Geneva highlights that an heterogeneous schooling population, a high level of per-pupil spending (Geneva has one of the highest level of per-pupil spending in Switzerland; OFS, 2007) and a large choice of secondary educational opportunities, do not suffice to ensure a successful integration of migrants. When ending compulsory school, recent and socioeconomically disadvantaged migrants are, more often than comparable natives, oriented to remedial education and not able to benefit from the apprenticeship system. This non-certifying year represents, de facto, an additional year of compulsory schooling and, by no means, a guarantee of better future educational opportunities. This ongoing issue has been recognized only recently by political authorities (CDIP, 2011), but certainly will be on the agenda for the next decade.

Our results also express the importance of tracking in fashioning post-compulsory school transitions. Above all, the system relies on "home-made" indicators when asserting students; if nationality does play a role, it is a much smaller one than track and schooling curriculum. Whether a student has repeated a year or ends up in the low track, sends a strong institutional signal about his supposed abilities, affecting his educational opportunities negatively. In this perspective, a legitimate question relates to the accuracy and flexibility of the tracking system: when and how exactly are students "labeled" and does the system really allow for labels to be modified over time? Those are interesting questions that should be addressed in further research. 


\section{References}

Angrist J, Lang K (2004) Does school integration generate peer effects? evidence from boston's metco program. The American Economic Review 94(5):1613-1634

Arum R (2000) Schools and communities: Ecological and institutional dimensions. Annual Review of Sociology pp 395-418

Bain D, Davaud C, Favre B, Hexel D, Jaeggi J, Lurin J, Rastoldo F, Soussi A (2000) Heterogeneite au cycle d'Orientation. Tech. rep., Service de la Recherche en Education, Geneva, Switzerland

Bourdieu P, Richardson JG (1986) The forms of capital. In: Handbook of Theory and Research for the Sociology of Education, Greenwood Press, p 401

Cameron A, Trivedi P (2005) Microeconometrics methods and applications. Cambridge University Press, Cambridge; New York

CDIP (2011) Projet transition: rapport final. Tech. rep., Conférence suisse des directeurs cantonaux de l'instruction publique (CDIP), Bern, URL http://www.cdip.ch/dyn/ 24197.php

Coleman JS (1988) Social capital in the creation of human capital. American journal of sociology pp 95-120

Dee TS (2005) A teacher like me: Does race, ethnicity, or gender matter? The American economic review 95(2):158-165

Driessen GW (2001) Ethnicity, forms of capital, and educational achievement. International Review of Education 47(6):513-538

Dustmann C (2004) Parental background, secondary school track choice, and wages. Oxford Economic Papers 56(2):209

Fuentes A (2011) Raising education outcomes in switzerland. Tech. Rep. no. 838, OECD, Paris

Gilbert G, Burnett M, Phau I, Haar J (2010) Does gender matter? a review of workrelated gender commonalities. Gender in Management: An International Journal 25(8):676-699

Greene WH (2011) Econometric Analysis, 7th edn. Prentice Hall

Hanushek EA, Woessmann L (2006) Does educational tracking affect performance and inequality? Differences-in-Differences evidence across countries. The Economic Journal 116(510):63-76

Hirschman C (2001) The educational enrollment of immigrant youth: A test of the segmented-assimilation hypothesis. Demography 38(3):317-336 
Krueger A, Summers L (1988) Efficiency wages and the inter-industry wage structure. Econometrica: Journal of the Econometric Society pp 259-293

Leslie D, Drinkwater S (1999) Staying on in full-time education: Reasons for higher participation rates among ethnic minority males and females. Economica 66(261):6377

Long JS, Freese J (2005) Regression Models for Categorical Dependent Variables Using Stata, Second Edition, 2nd edn. Stata Press

Loutfi M (2001) Women, gender and work: what is equality and how do we get there? International Labour Office, Geneva

Manski C (2000) Economic analysis of social interactions. Journal of Economic Perspectives $14(3): 115-136$

McFadden D (1973) Conditional logit analysis of qualitative choice behavior. In: Frontiers in Econometrics, academic press edn, P. Zarembka, New York, pp 105-142

Meunier M (2011) Immigration and student achievement: Evidence from switzerland. Economics of education review 30(1):16-38

Oakes J, Guiton G (1995) Matchmaking: The dynamics of high school tracking decisions. American Educational Research Journal 32(1):3

OCStat (2011) Population résidante selon l'origine et la nationalité. Tech. rep., Office Catonal de la Statistique (OCStat), Geneva, URL http://www.ge.ch/statistique/ domaines/01/01_02_1/tableaux.asp\#3

OECD (2007) The programme for international student assessment: PISA 2006. volume 2 Data/Données. Tech. rep., OECD, Paris, URL http://www.pisa.oecd.org/ document $/ 2 / 0,3746$, en_32252351_32236191_39718850_1_1_1_1,00.html

OFS (2007) Investissements dans l'éducation - dépenses publiques d'éducation par élève/étudiant. Tech. rep., Office fédéral de la statistique (OFS), Bern, URL http://www.bfs.admin.ch/bfs/portal/fr/index/themen/15/02/key/ind5. indicator. $51213.502 . \mathrm{html}$ ?open $=502 \# 502$

Rumbaut GR (1998) Ties that bind. In: Immigration and the Family: Research and Policy on US Immigrants., vol 54, Lawrence Erlbaum Associates, Mahwah, New Jersey, pp 457-475

Schneeweis N (2011) Educational institutions and the integration of migrants. Journal of Population Economics 24(4):1281-1308

Schweri J, Mueller B (2007) Why has the share of training firms declined in switzerland. Zeitschrift für ArbeitsmarktForschung; Journal for Labour Market Research 40(2/3):149-167 
Vellacott MC, Wolter S (2005) Equity in education thematic review country analytic report: Switzerland. Swiss Coordination Centre for Research in Education, Aarau

Zhou M, Kim S (2006) Community forces, social capital, and educational achievement: The case of supplementary education in the chinese and korean immigrant communities. Harvard Educational Review 76(1):1-29

\section{A Appendix}

Table A.1: Composition of selected nationality groups

\begin{tabular}{lllllllll}
\hline $\begin{array}{l}\text { Mediterr- } \\
\text { aneans }\end{array}$ & N & Percent & Others & N & Percent & $\begin{array}{l}\text { Balkans } \\
\text { \& Turks }\end{array}$ & N & Percent \\
\hline Spain & $2^{\prime} 712$ & 27.55 & Africa & $1^{\prime} 102$ & 41.09 & Balkans & 1 1'109 & 83.45 \\
Italy & $2^{\prime} 688$ & 27.31 & Asia & 581 & 21.66 & Turkey & 220 & 16.55 \\
Portugal & $4 ' 443$ & 45.14 & Middle & 154 & 5.74 & & & \\
& & & East & & & & & \\
& & & America & 845 & 31.51 & & & \\
\hline Total & $9^{\prime} 843$ & 100 & & $2^{\prime} 682$ & 100 & Total & $1^{\prime} 329$ & 100 \\
\hline
\end{tabular}

Source: Geneva Schooling Database (2007)

Table A.2: Origin and nationality

\begin{tabular}{lllllll}
\hline origin $\backslash$ nationality & Swiss & Balkans \& Turks & EU27 & Mediterraneans & Others & Total \\
\hline Swiss & $27^{\prime} 877$ & 319 & 1051 & 6 '176 & 761 & 36 '184 \\
Balkans \& Turks & 86 & 995 & 6 & 0 & 2 & 1'089 \\
EU27 & 537 & 10 & 685 & 36 & 65 & 1 1'333 \\
Mediterraneans & 105 & 0 & 17 & 3597 & 16 & 3 '735 \\
Others & 984 & 2 & 47 & 24 & 1823 & 2'880 \\
\hline Total & $29 ' 589$ & $1^{\prime} 326$ & $1^{\prime} 806$ & $9^{\prime} 833$ & $2 ' 667$ & $45 ' 221$ \\
\hline
\end{tabular}

Source: Geneva Schooling Database (2007)

Note: the discrepancies between totals in this table and table A.1 are due to the 413 cases where "origin" is missing 
Table A.3: Descriptive statistics

\begin{tabular}{lllll}
\hline & \multicolumn{3}{c}{ A } & \multicolumn{2}{c}{ B } \\
\hline & proportion & N & proportion & N \\
\hline girl & 52.56 & $16^{\prime} 750$ & 44.12 & $6^{\prime} 077$ \\
late & 7.09 & $2^{\prime} 258$ & 7.56 & $1^{\prime} 041$ \\
arrival: before school & 89.05 & $28^{\prime} 377$ & 74.41 & $1^{\prime} 249$ \\
arrival: preschool & 2.92 & 929 & 5.26 & 725 \\
arrival: primary school I & 2.32 & 738 & 5.48 & 755 \\
arrival: primary school II & 4.28 & $1^{\prime} 363$ & 10.95 & $1^{\prime} 508$ \\
arrival: middle school & 1.44 & 460 & 3.90 & 537 \\
white collars & 41.56 & $13^{\prime} 245$ & 31.04 & $4^{\prime} 276$ \\
directors & 25.56 & $8^{\prime} 145$ & 5.86 & 807 \\
self employed & 6.17 & $1^{\prime} 967$ & 6.83 & 941 \\
blue collars & 24.04 & $7^{\prime} 662$ & 49.30 & $6^{\prime} 791$ \\
misc. /NA & 2.66 & 848 & 6.96 & 959 \\
conventional family & 76.79 & $24^{\prime} 471$ & 69.77 & $9^{\prime} 610$ \\
non-french speaker & 28.90 & $9^{\prime} 211$ & 50.97 & $7^{\prime} 021$ \\
of foreign origin & 14.52 & $4^{\prime} 628$ & 31.80 & $4^{\prime} 380$ \\
Swiss & 73.41 & $23^{\prime} 395$ & 47.20 & $6^{\prime} 501$ \\
Balkans \& Turks & 1.68 & 535 & 5.76 & 794 \\
EU27 & 4.52 & $14^{\prime} 40$ & 3.22 & 444 \\
Mediterraneans & 15.30 & $4^{\prime} 875$ & 36.07 & $4^{\prime} 968$ \\
Others & 5.07 & $1^{\prime} 617$ & 7.73 & $1^{\prime} 065$ \\
\hline
\end{tabular}

Source: Geneva Schooling Database (2007) 
Cahiers de recherche du Centre de Recherche Appliquée en Gestion (CRAG) de la Haute Ecole de Gestion - Genève

(C) 2012

CRAG - Centre de Recherche Appliquée en Gestion

Haute école de gestion - Genève

Campus de Battelle, Bâtiment $\mathrm{F}$

7 , route de Drize - 1227 Carouge - Suisse

$\bowtie$ crag@hesge.ch

www.hesge.ch/heg/crag

(ग) +41223881818

岛 +41223881740

Tous les cahiers de recherche de la HEG sur RERO DOC : http://doc.rero.ch/collection/HEGGE i.REPORT?In=fr 